\title{
Analysis of Using Capital Asset Pricing Model for Assessing Companies Return
}

\author{
Burganova R. A. \\ Novak V. V. \\ Salahieva M. F. \\ Kazan Federal University, Institute of Management, Economics and Finance, Kazan, 420008, Russia
}

\section{Doi:10.5901/mjss.2014.v5n24p246}

\section{Abstract}

The article reveals the possibilities of using the bottom-up beta method in the Capital Asset Pricing Model (CAPM) as an alternative to regression analysis because of its limited using in the Russian realities. For this reason, the article presents the comparative analysis of methods for estimating the beta parameter. Having analysed the benefits and shortages of the approaches, in further calculations the authors focused on bottom-up beta approach for analogue companies, which takes into consideration fundamental parameters of company. To prove consistency of estimation of return of equity using the bottom-up beta method in the Capital Asset Pricing Model instead of "raw" beta, analysis of return of equity has been carried out in two ways. In confirmation of the advanced assumption, return of equity estimated by bottom-up beta method was more precise than using regression analysis in comparison with the real return of company's equity. Despite consistency of obtained estimation, it should be noted that this method requires further and deeper research and corrections due to a number of critical remarks made in the course of comparative analysis. In conclusion the authors propose recommendations for solving contradictory points identified during the analysis.

Keywords: Capital Asset Pricing Model, Bottom-up Beta Method, Risk and Uncertainty, Forecasting Stock Returns.

\section{Introduction}

It is well known that growth of investments in different sectors of national economy is of the essence for high rates of economic growth. Investments most actively provide for primary goal of financial management that is maximization of welfare of business owners by forming effective opportunities for its market value growth (Sharpe et al., 2007). Stable growth of capitalization of the company is one of the main indicators of its investment attractiveness. In this connection in the course of business it is important to monitor value fluctuations, which may be done with assessment of return of equity.

Requirement for definition of correct methods for assessment in Russian market is determined by low activity of foreign and domestic investors in terms of high risk and uncertainty. Such circumstances stipulate timeliness of the chosen subject.

In the wide sense, uncertainty implies the impossibility of event probability's calculation based on scientific background. Risk is a situation when an investor can evaluate the spread of possible returns of the investments and the certain event probability based on historical data or experts' opinion (Brealey et al, 2013).

Undoubtedly, the experience of the largest foreign investment companies and information agencies in the assessment of the equity's return must be carefully studied, analyzed and adapted to Russian condition (Damodaran, 2010).

\section{Methods}

In academic circles and in corporate financial management practice the most common method of ROE calculation is Capital Asset Pricing Model (CAPM), developed by W. Sharpe and J. Lintner (Sharpe, 1964; Lintner, 1965).

Expected return of equity capital $(R)$ we may express in terms of the following formula:

$R=R_{f}+\beta *\left(R_{m}-R_{f}\right)(1)$

where: $R_{f}$ - risk-free rate of return;

$\beta$ - coefficient characterizing systematic risk measure

$R_{m}$ - market rate of return;

$\left(R_{m}-R_{f}\right)$ - mean market risk premium. 
Beta coefficient expresses sensitivity of financial assets return to market risks and is calculated by the formula: $\beta=\frac{\operatorname{Cov}\left(K_{s}, K_{p}\right)}{\sigma_{p}^{2}}$

where: $\operatorname{Cov}\left(K_{s}, K_{p}\right)$ - covariation between return on equity of a company and market return;

$\sigma_{p}^{2}$ - variance of market rate of return.

Impropriety of using the model is seen mostly in developing markets because of the lack of informational effectiveness and low liquidity of assets. The distinctive feature of the developing markets is confined in the significance of the specific risks, related to government policy in regulation of the economy, institutional protection of investors and corporate management (Estrada, 2002).

Criticism towards CAPM model on the part of academic circles is focused mainly on inconsistency of its assumptions and practical application of regression analysis, which results in a so called "raw" beta (Blume, 1975; Levy, 1971). Taking into consideration specific nature of Russian capital market, which is characterized with low liquidity of small-cap stocks and dominance of some major companies, in many cases beta coefficients obtained by means of regression analysis are non applicable or require significant adjustments (Hwang and Pedersen, 2002; Barry et al., 2002). Therefore, the need arises to detect another method of beta coefficient assessment, that would allow to mitigate disadvantages of a traditionally used one.

Alternative approaches in estimation of beta parameters spread in emerging markets (including Russian market): Bottom-up beta method for analogue companies by R. Fuller and G. Kerr (Fuller and Kerr, 1981) and Accounting beta approach by N. Hill and B. Stone (Hill and Stone, 1980). Major differences are presented in Figure 1.
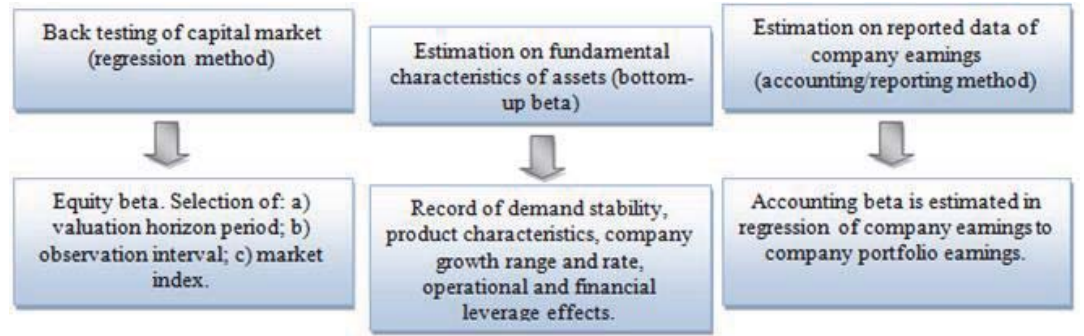

Figure 1. Beta coefficient structuring in fundamental effect characteristics (Teplova, 2013)

Having analysed the benefits and shortages of the said approaches, in further calculations we focused on bottom-up beta approach for analogue companies, which takes into consideration fundamental parameters of company, such as: specific nature of activity (range of activity, market value, life-cycle stage etc.); financial and operational leverage.

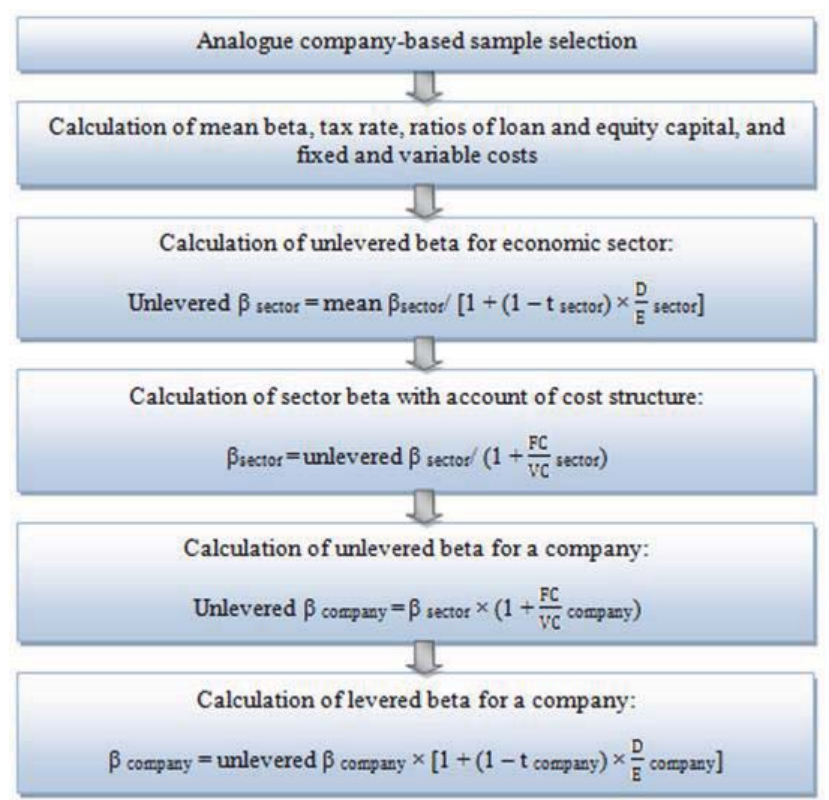

Figure 2. Bottom-up method computation algorithm (Guseinov, 2009) 
Such approach enables to take into account the tendencies of sector and specific nature of analysed company.

To prove consistency of estimation of return of equity using the bottom-up beta method in the CAPM instead of "raw" beta, analysis of return of equity of Russian telecommunication company MTS has been carried out in two ways.

Mobile TeleSystems Company OJSC (MTS) is a leading telecommunication operator in the Russian and CIS markets. It provides services to more than 102 million subscribers. From 2000, MTS securities are publicly traded on the NYSE. In 2013, MTS brand was in Top 100 Most Valuable Global Brands according to BRANDZ ${ }^{\text {TM }}$ rating and was recognized the most expensive telecommunication Russian brand (MTS, 2014).

Bloomberg data selection method has been used in the analysis: period: 2 years, stock price fixation frequency: weekly, observations quantity: 104 (Bloomberg, 2013).

Estimation by bottom-up beta approach for analogue companies may be presented as step-by-step algorithm shown in Figure 2. D should be understood as loan capital, E - equity capital, t - effective tax rate, FC - fixed costs, VC variable costs of company.

\section{Results}

Required data on stock quotes is on the open access in many Internet resources (Finam, 2013; Nasdaq, 2013). Regression method was used for "raw" beta calculation $(0,67)$. On the basis of statistical data calculation of average annual market return was carried out for the similar period $(68,12 \%)$ and risk-free rate (average annual government bond return) $-1,14 \%$.

Then expected return of MTS equity is:

$R=1,1403+0,6714$ * $(68,1227-1,1403)=46,11 \%$.

By algorithm shown in Figure 2, an analysis of telecommunication sector has been made and most successful public companies, as analogues of MTS, have been revealed. The list of indices required for further calculation is represented in Table 1.

Table 1. Data of analogue companies for bottom-up beta calculation

\begin{tabular}{|l|c|c|c|c|c|c|}
\hline Company & Country & $\begin{array}{c}\text { Market capitalization, USD } \\
\text { million }\end{array}$ & $\begin{array}{c}\text { Raw } \\
\text { betas }\end{array}$ & $\begin{array}{c}\text { Effective tax } \\
\text { rate, } \%\end{array}$ & $\begin{array}{c}\mathrm{FCl} \\
\text { VC }\end{array}$ & D/E \\
\hline MTS & Russia & 17228,00 & $\mathrm{X}$ & 29,35 & 0,69 & 1,21 \\
\hline China Mobile & Hong Kong & 172600,00 & 0,70 & 32,54 & 0,41 & 0,51 \\
\hline AT\&T & USA & 137380,00 & 0,61 & 33,98 & 0,28 & 1,39 \\
\hline Vodafone Group & Great Britain & 147230,00 & 0,74 & 24,91 & 0,30 & 0,63 \\
\hline Verizon Communications & USA & 108720,00 & 0,64 & 27,39 & 0,23 & 2,70 \\
\hline Comcast Corporation & USA & 88030,00 & 1,05 & 41,39 & 0,32 & 1,74 \\
\hline France Telecom & France & 72200,00 & 0,75 & 16,32 & 0,23 & 2,39 \\
\hline America Movil & Mexico & 71125,00 & 1,26 & 27,66 & 0,22 & 1,77 \\
\hline Deutsche Telekom & Germany & 69906,00 & 0,70 & 26,88 & 0,64 & 1,56 \\
\hline Telecom Italia & Italy & 40320,00 & 1,02 & 41,02 & 0,28 & 2,37 \\
\hline BCE Inc. & Canada & 27272,00 & 0,84 & 14,58 & 0,29 & 1,19 \\
\hline Average mean & $\mathrm{X}$ & 86546,45 & 0,83 & 28,73 & 0,35 & 1,59 \\
\hline
\end{tabular}

Data of market capitalization and beta coefficients were drawn from publicly open Internet sources (Bloomberg, 2013). Other calculations of the table are drawn on the basis of analogue companies' financial reporting (Ycharts, 2013). Effective tax rate for each company was determined by ratio of paid profit tax to profit before tax for the period.

As a result we have obtained the following industry-average indicators: "raw" beta $(0,83)$, effective tax rate $(28,73)$, fixed costs to variable costs ration $(0,35)$ and debt to equity ratio $(1,59)$.

Following the algorithm formulas, all sub-aggregates have been obtained: unlevered beta for sector $(0,39)$; beta for sector $(0,29)$; unlevered beta for MTS $(0,49)$ and beta for company $(0,90)$.

Basing on the data obtained, the results of expected return of MTS equity calculations are as follows:

$R=1,1403+0,9035 *(68,1227-1,1403)=61,66 \%$.

To determine correctness of returns assessment, calculation of actual return of equity has been performed. Return of MTS equity for the period made $67,48 \%$.

Variance analysis shows that analyst who selected the use of "raw" beta would mistake in expected return appraisal (estimated value $46,11 \%$ ) to 21,37 points in absolute terms. Forecasting return is lower than an actual one to 
$31,67 \%$. In case, if analyst prefers bottom-up beta approach, forecasting return would be equal to $61,66 \%$, which is below the actual one just to 5,82 points in absolute terms. In this case return of MTS equity is underestimated only to 8,62 $\%$.

Computational data confirmed consistency of put forward assumption and rate of return, calculated by bottom-up beta method, is closer to actual returns than calculation by means of classical regression analysis. "Raw" beta matched confidential interval $(0,67)$, but final returns estimation was much lower than the actual one.

According to bottom-up method, taking into consideration the trends in telecommunication and specific nature of company activity, the coefficient has been estimated at 0,9, which has corrected the predicted returns and maximally brought it towards its actual value.

\section{Discussion}

Despite consistency of obtained estimation, it should be noted that this method requires further and deeper research and corrections due to a number of critical remarks made in the course of comparative analysis:

1. Betas of analogue companies are calculated traditionally and can not fairly present the real state of companies and the sector (Collins, 2006; De Swaan and Liubych, 1999).

This problem is less evident and critical due to error smoothing in beta estimation by specification of sector average beta. So, average error mean is lower than beta error for one company.

2. During correction of average sectoral beta with consideration of operational and financial leverage and calculation of beta for company, the recent reporting data were used, thus neglecting the possibility of significant changes in capital structure or company expenditure in the following period (Serra, 2003).

This disputable moment is characteristic for estimation of capital structure and costs of analogue companies, the values of which effect the average sector mean values and beta for analysed company, consequently. It is possible to resolve differences by calculation of mean value of such correlations for companies for several preceding periods, but such analysis would take long and unlikely correct the final beta for the company.

3. Many companies do not disclose the structure of expenditure in their reports, that is why it takes a deeper analysis of expenditure items to specify expenditure character (Feldman, 2005).

Usually, the company's profit and loss account is used for analysis, where amortization and managerial costs are treated as fixed costs, while operating and selling costs are treated as variable costs. Although managerial costs may also depend on production volume, then cost structure value will be different.

4. Annual mean market return and financial instruments return, which are considered risk-free, also effect the forecasting return estimation. Values of those parameters directly depend on the period selected for data analysis, the frequency of price fixation by relevant instruments indices, which is another contradictory moment in estimation (Fernandez, 2004; Roll, 1977).

According to crisis period analysis, after-crisis returns are always understated, since it is based on data dynamics for previous periods, which reflect generally recession in stock market. And degression of return on equity, which is not stipulated by the general recession in the market or in the sector, is faintly detected by bottom-up beta method of analogue companies.

\section{Conclusion}

At present there is a need for adjustments to the methodology for assessing the return of equity of Russian companies in connection with the necessity of taking into account peculiarities of the Russian market as a whole.

It is known that there are a number of critical remarks concerning prerequisites of the Capital Asset Pricing Model and traditional algorithm for calculating the parameter beta. Therefore there is a need to use another method for calculating the beta that provides more correct results.

Analysis of alternative methods for the assessment of return of equity allows to select the bottom-up beta method for analogue companies, which takes into account specifics of the company and trends of the industry.

In confirmation of the advanced assumption, return of equity estimated by bottom-up beta method was more precise than using regression analysis in comparison with the real return of company's equity.

We have developed recommendations for leveling controversial issues detected in the process of the beta estimation. But it should be noted, that detailed analysis of all factors affecting the final index of forecasting return is required. 


\section{References}

Barry, C., E. Goldreyer, L. Lockwood and M. Rodrigues, 2002. Robustness of Size and Value Effects in Emerging Equity Markets, 19852000. Emerging Markets Review, 3 (1): 1-30. DOI: 10.1016/S1566-0141(01)00028-0.

Blume, M.E., 1975. Betas and Their Regression Tendencies. Journal of Finance, 30 (3): 785-795. DOI: 10.1111/j.15406261.1975.tb01850.x.

Brealey, R., S. Myers and F. Allen, 2013. Principles of Corporate Finance. McGraw Hill, Irwin. ISBN: 978-0078034763, pp: 976.

Collins, D., 2006. Measuring the Cost of Equity in Frontier Financial Markets. Research in Accounting in Emerging Economies, 7 (1): 457-492. DOI: 10.1016/S1479-3563(06)07021-6.

Damodaran, A., 2010. Investment Valuation: Tools and Techniques for Determining the Value of Any Asset. 6 ${ }^{\text {th }}$ Ed. Alpina Business Book, Moscow. ISBN: 978-5961411522, pp: 1344.

De Swaan, J. and A. Liubych, 1999. Determining the Cost of Equity in Emerging Markets. Harvard Kennedy School. Working paper, 28. http://www.ksg.harvard.edu/PAE. (Accessed on June 17, 2013).

Estrada, J., 2002. Systematic Risk in Emerging Markets: the D-CAPM. Emerging Markets Review, 3 (4): 365-379. DOI: 10.1016/S15660141(02)00042-0.

Feldman, S., 2005. Principles of Private Firm Valuation. J. Wiley \& Sons. ISBN: 978-0471487210, pp: 192.

Fernandez, P., 2004. Market Risk Premium: Required Historical and Expected. IESE Business School. Working paper, 574. http://www.iese.edu/research/pdfs/di-0574-e.pdf (Accessed on June 15, 2013).

Fuller, R. and H. Kerr, 1981. Estimating the Divisional Cost of Capital: an Analysis of the Pure-Play Technique. Journal of Finance, 36 (5): 997-1009. DOI: 10.1111/j.1540-6261.1981.tb01071.x.

Guseinov, B.M., 2009. Problems of Beta Coefficient Calculation in Estimation of Return of Equity by the CAPM for Russian Companies. Financial Management, 1: 76-83. ISSN: 1607-968X.

Hill, N. and B. Stone, 1980. Accounting Betas, Systematic Operating Risk and Financial Leverage: A Risk-Composition Approach to the Determinants of Systematic Risk. Journal of Financial and Quantitative Analysis, 15 (3): 595-637. DOI: 10.2307/2330401.

Hwang, S. and S. Pedersen, 2002. Best Practice Risk Measurement in Emerging Markets: Empirical Test of Asymmetric Alternatives to CAPM. Cass Business School. Working paper, 8. DOI: 10.1.1.11.7565.

Bloomberg, 2013. Data of market capitalization and beta coefficients. http://www.bloomberg.com/quickview. (Accessed on July 07, 2013).

Finam, 2013. Data on stock quotes. http://www.finam.ru/analysis. (Accessed on July 05, 2013).

Nasdaq, 2013. Data on stock quotes. http://www.nasdaq.com/quotes. (Accessed on July 05, 2013).

Ycharts, 2013. Financial reporting. http://ycharts.com/companies/stock_center. (Accessed on July 07, 2013).

Levy, R.A., 1971. On the Short-Term Stationarity of Beta Coefficients. Financial Analysts Journal, 27 (6): 55-62. DOI: 10.2469/faj.v27.n6.55.

Lintner, J., 1965. The Valuation of Risk Assets and the Selection of Risky Investments in Stock Portfolios and Capital Budgets. Review of Economics and Statistics, 47 (1): 13-37. http://www.jstor.org/stable/1924119. (Accessed on June 14, 2013).

MTS OJSC, 2014. Official international web-site. http://www.mtsgsm.com/about. (Accessed on February 21, 2014).

Serra, A.P., 2003. The Cross-Sectional Determinants of Returns: Evidence from Emerging Markets' Stocks. Journal of Emerging Market Finance, 2 (2): 123-162. DOI: 10.2139/ssrn.264658.

Sharpe, W.F., 1964. Capital Asset Prices: A Theory of Market Equilibrium under Conditions of Risk. Journal of Finance, 19 (3): $425-442$. DOI: 10.1111/j.1540-6261.1964.tb02865.X.

Sharpe, W.F., G.J. Alexander and J.V. Bailey, 2007. Investments. Infra-M, Moscow. ISBN: 978- 5160025957, pp: 1028.

Roll, R.A., 1977. Critique of the Asset Pricing Theory's Tests. Journal of Financial Economics, 4: 129-176. DOI: http://schwert.ssb. rochester.edu/f532/JFE77_RR.pdf. (Accessed on June 10, 2013).

Bagautdinova, N., Tsaregorodtsev E., Kulalayeva I., Arzhantseva N. Assessment of Mutual Probabilistic Influence of Volatility of Official Price for Precious Metals on the Market Value of the Bi-Currency Basket// Mediterranean Journal of Social Sciences.- Vol.5, No12, (2014)-pp.33-38.

Teplova, T.V., 2013. Investments: Textbook for Bachelor Programme. Uright, Moscow. ISBN: 978-5991626408, pp: 736. 